\title{
THEORETICAL EFFICIENCY IN POLLUTION CONTROL: COMMENT
}

\author{
DONALD C. SHOUP \\ University of Michigan
}

In a recent issue of this Journal, Richard O. Zerbe [7] considered the effects of alternative assignments of liability for damage in the field of pollution control and presented a useful categorization and analysis of alternative methods of achieving any particular level of control. In the process, Zerbe makes some rather strong claims for the "Coase theorem" which deserve further discussion. For instance, Zerbe says that

Application of the Coase theorem shows that, with a costless pricing system, bargaining would achieve alike a socially acceptable pollution level and the adoption of efficient techniques for reaching this level. Further, these results would be invariant with respect to liability $[7$, p. 365].

However, quite aside from the obvious fact that the assignment of liability for pollution has consequences for the distribution of wealth and thus for which a Pareto-efficient ("socially acceptable?") result is obtained, it is not clear that the attainment of a Pareto-efficient level of pollution really is invariant with respect to liability. The reason that this is not clear stems from the complex game situations that can result from the unambiguous assignment of liability for pollution. Rather, the necessary bargaining is perhaps better described in terms of game theory than in terms of a "pricing system," and the assignment of liability for pollution might lead to a game situation where the assumption of a jointmaximum solution is questionable. The purpose of this note is to draw attention to some of the seemingly inevitable game consequences that would attend a reliance on assignment of liability and bargaining to solve a pollution problem, and to suggest a few undesirable types of strategic behavior that are subsumed under the rather colorless term "transaction costs."

For example, consider the situation where no polluter is held liable for external costs arising from his production activities. Now it may be true that in this case the "victims" of the pollution can bribe the polluter to reduce his pollution or can adjust their own behavior so that the sum of the net social benefits accruing to both the polluter and victim are maximized. But the bargaining process would surely not stop there. Once it became apparent that polluters could extract payments for pollution reduction, there would be an incentive for entrepreneurs to threaten to undertake production activities with external pollution costs simply to be bribed not to undertake them. Furthermore, a pollution entrepreneur might actually have to invest resources, and he might 
have to pollute, solely to make his threats credible, a clear social loss. If the expected value of bribes received for not polluting exceeds the cost of making the threats plus the threatener's negotiating costs, there will be an incentive to devote resources to threatening. The threat to pollute, and bargaining for a bribe not to pollute, need not, of course, come only from entrepreneurs who are in business only for such purposes. For instance, an oil company interested in the location for a new refinery might "consider" several populated sites for the purpose of being paid not to locate there, especially if it were actually indifferent among these sites on considerations of refinery profit alone. Such threats could also be made on a small household scale, as by burning rubbish or tires in a back yard simply in order to be bribed not to do so by one's neighbors. The result could be a sort of environmental "protection racket," with much pollution undertaken solely for bargaining purposes, and with little hope of a Pareto-efficient, much less stable, solution. ${ }^{1}$

Zerbe maintains that "whether or not negotiations take place is a question of whether or not there are gains from trade." But this implies that the only choice is between a positive-sum and a zero-sum game, and that the games are always cooperative. The legal sanctioning of pollution may also encourage negative-sum games, so long as the polluter or pollution threatener expects to gain, and even if he expects to gain less than the victim loses. ${ }^{2}$

In the absence of a generally established solution to such game situations, the assumption of a joint-maximum solution is questionable $[1$, p. 8$]$. It is especially questionable when, as in the pollution game, the bargaining is not only between individuals who can, at worst, refuse to cooperate, but also between those who can harm one another, or when only one party can harm several others (as when one air polluter is "upwind" of all others). Thus, it would not generally be true that "the polluter's incentive to negotiate is not determined by his liability" [7, p. 366]. Likewise, similar bargaining by "victim entrepreneurs" would also seem inevitable if the polluter were made liable to the victim for any external costs he imposes. In this case, potential "victims" would have an incentive to threaten to locate in polluted areas adjacent to pollution producers, in order to be bribed not to locate in such areas. Again, these individuals could invest resources to make their threats credible, as by purchasing property and undertaking residential construc-

1. Mishan $[5$, p. 24$]$ refers to such unnecessary pollution as "malpractices," but it should be clear that it could be common practice, just as military expenditures and strikes are familiar strategic phenomena.

2. The pollution game would then have the characteristics of what Schelling calls a "variablesum, variable-proportions game" $\{6$, p. 89]. 
tion, if the expected value of the bribe not to locate in the polluted area exceeded the cost of making the threat. ${ }^{3}$ It should also be noted that if the polluter is liable to the government for pollution damages, then potential victims have no incentive to threaten polluters, for the victim would receive none of the damage awards. ${ }^{4}$

In addition to the possibility of intentional pollution damage done in the bargaining process, there is also a more familiar problem that may prevent a Pareto-efficient level of pollution. If, as is almost always the case, the same noise, air, or water pollution enters negatively into many individuals' utility functions, the pollution has the additional properties of a "public bad." As with public goods, any single victim has little incentive to enter into negotiations to reduce the quantity of the public bad produced; an individual will be tempted to be a "free rider," paying nothing for whatever level of pollution abatement is eventually negotiated. Again, no theoretical solution to the free-rider game problem, in regard to either public goods, or bads, has been established.

From these few examples, it seems clear that one important but underemphasized aspect of Coase's theorem for the study of the economics of pollution is to direct attention to game theory for insight into what might be expected to result from alternative assignments of liability for pollution damage. Indeed, the very meaning of the term "transaction costs" in this context must be found in game theory, and the meaning and measurement of transaction costs is of crucial importance for drawing conclusions from Coase's analysis, for as Calabresi $[2$, p. 68] has pointed out, "if one assumes rationality, no transaction costs, and no legal impediments to bargaining, all misallocations of resources would be fully cured in the market by bargains. Far from being surprising, this statement is tautological, at least if one accepts any of the various classic definitions of misallocation." The Coase theorem "read as a kind of Say's law of welfare economics" [2, p. 73] directs attention to important questions, though it does not itself provide any answers in the absence of at least theoretical solutions to numerous game problems.

It is interesting to note that the pollution policies alternative to assignment of liability, such as pollution quotas, direct damage taxes, emission taxes, etc., which Zerbe lists, would usually not result in such

3. It is, of course, possible to permit certain forms of pollution in some geographic areas, and prohibit them in others. This is the "separation of facilities" approach recommended by Mishan [4] and is roughly similar to conventional municipal zoning. This technique should perhaps be added to Zerbe's useful list of possible methods to allevinte pollution.

4. However, as Coase [3] shows, taxing the polluter in proportion to the external costs of his pollution may hinder negotiations between polluter and victim in those cases where negotiation alone might bring about a joint-maximum level of welfare. Apparently, neither form of liability is entirely salisfactory. 
complex game situations as would be produced by simple assignment of liability, and the costs of these alternative policies are therefore more easily understood with conventional economic analysis.

\section{REFERENCES}

1. K. J. Arrow, "Political and Economic Evaluation of Social Effects and Externalities," in The Analysis of Public Output, ed., J. Margolis, New York 1970.

2. G. Calabresi, "Transaction Costs, Resource Allocation and Liability Rules-A Comment," Jowr. Law and Economics, Apr. 1968, 11, 67-73.

3. R. H. Coase, "The Problem of Social Cost," Jour. Law and Economics, Oct. 1960, 3, 1-44.

4. E. J. Mishan, "Pareto Optimabity and the Law," Oxford Econ. Papers, Nov, 1967, 19, 255-87.

5. _The Postwar Literature on Externalities: An Interpretative Essay," Jour. Econ. Lit., Mar. 1971, 9, 1-28.

6. T. C. Schelling, The Strategy of Conflict. Cambridge 1963.

7. R. O. Zerbe, "Theoretical Efficiency in Pollution Control," Westem Econ. Jowr., Dec. 1970, 8 , 364-76. 